\title{
Assessing the Labour Government's new procurement approach through a Māori economic justice perspective
}

\author{
Katharina Ruckstuhl (Ngāi Tahu), Sequoia Short (Ngāti Apakura) \& Jeff Foote \\ University of Otago, Aotearoa New Zealand
}

\begin{abstract}
INTRODUCTION: Social procurement-the intentional generation of social value through an organisation's procurement and commissioning processes-is being adopted globally and in Aotearoa New Zealand as progressive social policy. Some of the issues that lie behind calls for economic justice, such as economic opportunity, rights for vulnerable workers, and unemployment, may be addressed through social procurement. While Māori may also benefit from this, there are other factors that should be considered from a Te Tiriti perspective.
\end{abstract}

METHOD: In this research brief, we outline the context behind the government's current initiatives, drawing on policy and research literature as part of a scoping study aimed at developing a Te Tiriti approach to social procurement.

CONCLUSION: We conclude by noting the opportunities for economic justice for Māori, but also some of the caveats drawn from international and Aotearoa New Zealand literature.

Keywords: Economic justice; social procurement; Māori; Te Tiriti
The New Zealand government is currently touting social procurement-that is, the intentional generation of social value through procurement and commissioning processes (Furneaux \& Barraket, 2014; Hurt-Suwan \& Mahler, 2020)_as a tool of economic justice, particularly for Māori (Nash \& Jackson, 2020). Issues central to economic justice include rights in the workplace, economic opportunity, rights for vulnerable workers, and initiatives that assist or alleviate those who are unemployed, under-employed, never employed or precariously employed (Simmons, 2017).

All organisations procure goods and services with rules and processes around how this occurs (Wisner et al., 2012). In late 2020, the Government set a target that five percent of public sector contracts should be awarded to Māori, with Te Puni Kōkiri trialling approaches over 2021 as to how this might be best achieved (Ministry of Business, Innovation and Employment [MBIE], 2020b). The government has obligations under Te Tiriti o Waitangi to uphold and give effect to the principles of partnership, participation and protection (Hudson \& Russell, 2009), obligations that include economic development (Greig, 2010). From an economic partnership, participation and protection perspective, the government might be said to have failed in upholding these principles given that Māori
AOTEAROA NEW ZEALAND SOCIAL WORK 33(4), 47-54.

CORRESPONDENCE TO: Sequoia Short sequoia.short@otago.ac.nz 
make up $12 \%$ of New Zealand's labour force, yet Māori are unemployed $(23 \%)$ or underemployed (22.8\%) (MBIE, 2020a). There are higher proportions of Māori in lower-skilled occupations and industries that are vulnerable to technological changes and economic downturns (MBIE, 2017b). This situation has an intergenerational impact, with Māori children more likely to live in households with lower income or increased material hardship (Statistics New Zealand, 2020).

Hence, social procurement initiatives are interventions aimed at addressing a number of issues that are core to economic justice. However, while government aspirations are high, many changes will need to occur across both the procuring and procuree organisations before social procurement can facilitate economic justice. In this research brief, we review the context that lies behind the government's social procurement initiatives and outline some of the enablers and barriers to achievement, particularly for Māori. We also briefly report on initial findings from interviews with 10 procurement specialists as part of an exploratory study to understand social procurement in terms of Te Tiriti o Waitangi (Short, 2021). Some implications for social work practice are discussed at the end.

\section{What is social procurement?}

The notion of using purchasing power to create additional value is central to social procurement and is being adopted as progressive social policy in Aotearoa New Zealand. Social procurement is the intentional creation of social benefit through purchasing of assets and services outside of typical requirements (Burkett, 2010; Collins, 2006; Furneaux \& Barraket, 2014). In Aotearoa New Zealand, both central and local government procurement falls into a two-tier system: contracts under $\$ 100,000$ and those above. Those contracts that are valued $\$ 100,000$ or more are listed on the Government Electronic Tender Service
(GETS) where all registered business can access and apply to fulfil it. To tender for a contract, suppliers must indicate in a written document or bid how they can meet and deliver the contract obligations. These bids are then assessed and evaluated by the organisation that listed them to determine who is awarded the contract. Contracts valued less than $\$ 100,000$ are left for procurement staff to find an appropriate number of quotes from businesses they have existing relationships with, or who are found during market research. These quotes are then compared and evaluated so the contract can be awarded (MBIE, n.d.-a).

A traditional approach sees suppliers evaluated on the price, quality and delivery of goods or services (Lysons \& Farrington, 2006; Wisner et al., 2012). Other criteria may include quality and process control, continuous improvement, facility environment, customer relationships, delivery, inventory and warehousing, ordering, financial conditions and certification (Simpson et al., 2002). However, creating social value using procurement processes and purchasing power is different from traditional procurement practices. In other words, the focus is not only on the good or service, its price point and the relationship with the supplier, but also on external considerations such as addressing social requirements like precarious employment where there are low wages, job insecurity and lack of rights and protections (Kreshpaj et al., 2020).

In the public sector, there is a heavily regulated competitive bidding system for contracts. This ensures public transparency with free entry of qualified bidders and explicit, objective selection criteria (Bajari et al., 2009; Tadelis, 2012). In comparison, the private sector has flexibility and can utilise mechanisms other than auctions to select suppliers and the criteria by which bids are judged. This can create an environment in which existing suppliers may be given preference and the judgement of bidding becomes more subjective. However, both 
public and private organisations can leverage their purchasing power and procurement pathways to create positive social, environmental, and economic outcomes (Mupanemunda, 2019). These benefits can be direct, such as when an organisation in a targeted group receives direct financial benefit, and indirect, spillover benefits such as increased whānau wellbeing, cultural connection, or community employment.

Entities can create social value when they can influence the procurement processes described earlier in ways that generate positive social outcomes, such as inclusion and empowerment of targeted groups in the supply chain and/or the supplier's workforce (see Box 1 for example). The procuring organisation can integrate specific outcomes within the planning and evaluation stages of procurement by adding criteria such as environmental sustainability or social good initiative. However, as our discussions with procurement specialists reveal, this is not standard industry practice unless it is considered specifically relevant to any given project or purchase, and so may be challenging to implement.

\section{What is the opportunity for Māori through social procurement?}

The government spends an estimated $\$ 41$ billion annually on the procurement of goods and services (MBIE, 2017, p. 9), with expenditure guided by the Progressive Procurement Policy (MBIE, 2020b). In late 2020, the government announced that at least $5 \%$ of contracts were expected to be awarded to Māori businesses, defined

\section{Box 1: Poverty Alleviation and Social Procurement. 2015 Pan AM Games, Canada}

Australia is not alone in implementing Indigenous social procurement policies. Here we outline a successful example of social procurement in Canada. From this, there are lessons for Aotearoa New Zealand from a poverty alleviation perspective.

In 2012, the Toronto City Council unanimously decided that procurement activities should also provide social value during the preparation and execution of the 2015 Pan Am games (Toronto City Council, 2016). Event organisers were intent on using social procurement policy as a means to alleviate systemic poverty through increasing the employment, apprenticeship, and training opportunities for identified groups.

However, the desire to engage with minority-owned businesses was constrained by the need for contracts to be financially competitive, which can be difficult for a minority-owned business as minority businesses are on average, smaller. To mitigate this issue, a points system was developed to assess bids in relation to social objective and minority ownership (Kimel, 2015).

Contracts of $\$ 7.3$ million (8\% of total value of contracts) were awarded to 226 businesses ( $20 \%$ of total suppliers) including those owned by women, visible minorities, aboriginals, persons with disabilities and LGBT for procurement of goods and services such as food and merchandise (Toronto2015, 2015).

Key learnings from this project are that a points-based system favouring minority, and including Indigenous businesses, can still meet the conditions of an open market context. However, the other main learning is that the majority of expenditure was in areas that small businesses were non-competitive, such as construction. Hence, relying on "one-off" social procurement as a poverty alleviation method is unlikely to meet such a broader objective. 
as having at least 50\% Māori ownership or being classified as a Māori Authority by the Inland Revenue Department. This approach is largely inspired by Australian initiatives, with a claim that for every dollar of indigenous procurement there was a $\$ 4.41$ indirect benefit of economic and social value that includes connection to culture, training of employees, pride, and reinvestment in the community (Supply Nation, 2018). Comparative analysis of non-Indigenous suppliers has not been undertaken or is not readily available.

In Aotearoa New Zealand, the policy aims to assist economic recovery in the wake of Covid-19 and act as a tool to improve cash flow and diversify customers for Māori businesses to improve the resilience of the Māori economy (Nash \& Jackson, 2020). The policy applies to all government agencies including the Police and Defence Forces and Crown Research Institutes that are required to report progress towards the target (MBIE, 2020b).

As part of the government's overall 2019 reforms of the procurement "Rules of Sourcing," there is now a clause to acknowledge "the pre-eminence of Te Tiriti o Waitangi...to provide[s] flexibility for the Government to implement domestic policies in relation to Māori, including in fulfilment of the Crown's obligations under the Treaty [emphasis added]". This enables government agencies to "accord favourable treatment to Māori, provided that such measures are not used as a means of arbitrary or unjustified discrimination or as a disguised restriction on trade in goods, trade in services and investment" (MBIE, 2019, p. 6).

From a practical perspective, what does "accord favourable treatment to Māori" mean? Within the Rules of Sourcing document, an example is given when a procuring agency wishes to contract for goods or services below a threshold of $\$ 100,000$. In such cases, the agency "should consider if there is a capable Aotearoa New Zealand business, including Māori businesses, Pasifika businesses and social enterprises that could fulfil the contract opportunity". This is in line with the Government's desire to support local small and regional businesses (MBIE, n.d.-b). This new approach is being spearheaded through Te Kupenga Hao Pāuaua, a new team at Te Puni Kōkiri (TPK). In particular, support for small Māori businesses or organisations is being directed to services such as cleaning, catering, consultancy and design (TPK, 2021), areas identified by the government as having the most potential for small business economic outcomes. A number of iwi and Māori collectives have been organising themselves to win such contracts (see, for example, Te Matarau A Māui, n.d.; Trust Tairāwhiti, 2020).

However, what about contracts above $\$ 100,000$ ? In such cases, because Aotearoa New Zealand has signed a number of Free Trade Agreements (FTAs) that allow for international bidders, procuring agencies need to be explicit about why they would prefer a Māori supplier. Aotearoa New Zealand has a number of FTAs that outline how countries treat each other when doing business together, including importing and exporting goods or services and investing. While reducing tariffs and encouraging trade are main features, FTAs also allow foreign organisations to compete for government tenders for goods and services on a non-discriminatory basis in each other's markets (Ministry of Foreign Affairs \& Trade [MFAT], n.d.). There are carve outs in these international agreements to acknowledge Te Tiriti obligations to, for example, uphold traditional knowledge and cultural expressions in intellectual property, protect indigenous plant species, and implement policies that benefit Māori without being obliged to offer equivalent treatment to other persons (MFAT, n.d.). Current procurement rules state that tenders for construction projects over $\$ 10$ million, and for goods and services to central government entities over $\$ 260,000$, and other government groups such as Defence over $\$ 800,000$, are required to be open to international bidders. Benefitting Māori without being obliged to offer equivalent treatment to others requires 
an agency to consult with the Trade Law Unit at the Ministry of Foreign Affairs and Trade to ensure adherence to these international agreements.

Currently, it is unclear what such a tender process might look like and the circumstances under which this might occur. It is also unclear what legal complications this might encounter in relation to Aotearoa New Zealand's FTAs (Kawharu, 2016). Speculatively, and in the spirit of the Tiriti partnership and a tribal authority's right to self-determined economic development, large favourable procurement contracts might become part of a prospective Te Tiriti o Waitangi settlement at local, or even national, levels. However, this remains an unexplored avenue. In the meantime, as the Canadian case study indicates, the ability of small- and medium-sized businesses to be competitive in large tenders is limited.

One way that an agency can ensure broader social considerations are fulfilled in larger contracts is by incorporating particular requirements when considering and awarding tenders. Social value can be achieved, not only in contracting a minority vendor, but also by requiring that in large contracts, targeted groups are offered employment, training opportunities, health benefits, wage increases or other benefits that lie outside of what is legally required. Such a shift away from "standard" employment requirements can give opportunities to targeted groups, particularly those who are unemployed, under-employed, or precariously employed (Troje \& Andersson, 2020; Troje \& Kadefors, 2018). For example, Hurt-Suwan and Mahler (2020) found that social procurement can reduce precarious employment in the Aotearoa New Zealand construction industry by improving the skills and capabilities of employees.

\section{Māori values and procurement decision-making}

While poverty alleviation and improved economic prosperity are undoubtedly key drivers of social procurement, a Māori perspective offers additional factors that require consideration. The "Government Procurement Charter" outlines expectations as to how procurement activities are to achieve public value (MBIE, 2021). Value is defined as good quality (effective and efficient), outcomes (economic, environmental, cultural, and social), and price (upfront and ongoing). As our brief overview of traditional, Eurocentric procurement practices explained, typical assessment metrics have been around cost, experience, or quality. How, then, can the new expectations, particularly around economic, environmental, cultural, and social outcomes, be aligned to Māori expectations of success?

As part of an exploratory study into Te Tiriti based social procurement, 10 procurement specialists were interviewed about their experience of and suggestions for implementing and achieving the new Te Tiriti expectations. Our key findings showed that, while the procurement specialists recognised Te Tiriti obligations, many were uncertain as to how to implement them. Within the tender construction process itself, some practitioners identified the planning phase as an area where Te Tiriti clauses might be included. This phase consists of outlining the objectives and expectations of a purchase/ contract because a key component of this phase is determining the criteria against which a tender is assessed to meet the desired outcomes. The informants also recognised that there was a complex mix of government, professional procurement networks, stakeholders, and intermediaries or those who broker relationships, that are involved in establishing procurement processes and values, meaning any number of groups may have influence over procurement processes.

This complexity and uncertainty in relation to the actual process of preparing for, awarding, and then monitoring a tender, suggests that there is still a long way to go to achieve the intent of the new 
procurement rules. From an Indigenous perspective, Australian research suggests that Indigenous procurement frameworks are still rare (Denny-Smith et al., 2020). Indigenous cultural knowledge and values are not necessarily transferable between indigenous groups suggesting there is no one procurement approach at the organisational level. Given the changes to social procurement policy are still very new, frameworks that might guide procurement from a Māori perspective have yet to be developed. For example, how might te reo Māori, cultural concepts and values such as mana, whakapapa and manaakitanga (Came et al., 2020) be integrated into a Tiriti-focussed procurement framework? Māori control and ownership is guaranteed in Te Tiriti (Moewaka Barnes, 2009), but seemingly constrained within even the current new procurement rules. Moreover, there may be unintended consequences. For example, social procurement should not become a "double-tax" on Māori organisations to shift problems such as under-employment or unemployment away from government or corporate responsibility and on to Māori organisations (Cutcher et al., 2020).

\section{Conclusion}

Throughout the world, social procurement is being used as a means to benefit marginalised groups, including Indigenous communities with a focus on the creation of social value by altering the requirements for and outcomes of mainstream procurement practices (Mccrudden, 2004; McNeill, 2015; Howells et al., 2020; Loosemore, 2016). As we have shown, opportunities for Māori through the new Te Tiriti procurement clause appears to offer some opportunity in relation to contracts under $\$ 100,000$. However, as we have also shown, Māoriowned ventures, like other New Zealand organisations, have to compete in an international environment when it comes to larger contracts.

This raises the question of whether there is a level-playing field. Self-determined
Māori economic development has been held back due to failure to respect and honour Te Tiriti, viewed by some as a deliberate "dismembering" of the Mãori economy (Henare et al., 2014; Pool, 2015, p. 253) and the promise of a quality of life as determined by Māori. While there is the ability to insert clauses into larger contracts to meet certain targets-such as employment and training of under-represented groups-this does not get away from the fact that, in such cases, Māori are reliant on third parties to "do the right thing," that is, there is a lack of Māori control, guaranteed under Te Tiriti. Moreover, while procurement practitioners want to enable Te Tiriti obligations, the practical mechanisms, broader networks, training, and capabilities to execute this are still in their infancy. Māori-oriented concepts and practices that might feed into these process-such as mana, whakapapa and manaakitanga-are not yet apparent.

As a mechanism for economic justice, social procurement has merit; hence there has been an enthusiastic response from Māori. In response to this, social work providers should consider the extent to which social procurement might fit into their operations. At the individual and organisational levels, social workers will need to understand the government's procurement approach in order to identify under what circumstances it might be a pathway for particular individuals or groups. This might involve developing relationships with Māori collectives, whether iwi, hapū or private sector, to identify capability training for procurement tendering. There is also a case for cross-government co-ordination, at both central and local levels, to identify which types of tenders have the potential to provide social and cultural benefits to Māori as well as economic benefits such as employment. Finally, developing metrics of success will also be necessary, particularly metrics that Māori value. However, as international research has shown, there are also caveats, with the need for ongoing and mindful research in this area, particularly as it intersects with social work practice. 


\section{Funding statement}

Ngā Pae o Te Māramatanga supported the literature review. Contract no. ID20INT47.

Accepted 12 November 2021

Published 23 December 2021

\section{References}

Bajari, P., McMillan, R., \& Tadelis, S. (2009). Auctions versus negotiations in procurement: An empirical analysis. Journal of Law, Economics, and Organization, 25(2), 372-399. https://doi.org/10.1093/jleo/ewn002

Burkett, I. (2010). Social procurement in Australia. https://www.csi.edu.au/media/uploads/Social_ Procurement_in_Australia_Report_-_December_2010.pdf

Came, Warbrick, I., Doole, C., Hotere-Barnes, A., \& Sessa, M. (2020). He hokinga ki te mauri: Strengthening te Tiriti o Waitangi public health education in tertiary education settings. Teaching in Higher Education, 25(8), 926-941. https://doi.org/10.1080/13562517.2019.1613357

Collins, A. (2006). The scope for using social clauses in UK public procurement to benefit the UK manufacturing sector. A Report for the Manufacturing Forum. THE RESEARCH TEAM. https://www.ratransport.co.uk/ images/Report Final 21July06.pdf

Cutcher, L., Ormiston, J., \& Gardner, C. (2020). "Doubletaxing" Indigenous business: exploring the effects of political discourse on the transfer of public procurement policy. Public Management Review, 22(9), 1398-1422. https://doi.org/10.1080/14719037.2019.1679235

Denny-Smith, G., Williams, M., \& Loosemore, M. (2020). Assessing the impact of social procurement policies for Indigenous people. Construction Management and Economics, 38(12), 1-19. https://doi.org/10.1080/01446 193.2020.1795217

Furneaux, C., \& Barraket, J. (2014). Purchasing social good(s): A definition and typology of social procurement. Public Money and Management, 34(4), 265-272. https://doi.org/10.1080/09540962.2014.920199

Greig, E. (2010). The Māori right to development and new forms of property. (Unpublished honours dissertation) The University of Otago.

Henare, M., Lythberg, B., \& Woods, C. (2014). Teaming with intent: harmonising heritage, innovation and multiple generations within the Māori entrepreneurial team. The Business \& Management Review, 5(1), 465-477. http:// search.proquest.com/openview/e4761c3d75bf4fc24b89c 967696764da/1?pq-origsite=gscholar\&cbl=2026610

Howells, L., Parfitt, S., Robinson, S., Sarter, E. K. (2020). New development: Myth or reality? The public sector's growing appetite to procure from the third sector. Public Money \& Management, 40(2), 170-173.

Hudson, M. L., \& Russell, K. (2009). The Treaty of Waitangi and research ethics in Aotearoa. Journal of Bioethical Inquiry, 6(1), 61-68. https://doi.org/10.1007/s11673-0089127-0

Hurt-Suwan, C. J. P., \& Mahler, M. L. (2020). Social procurement to reduce precarious employment for Māori and Pasifika workers in the construction industry. Kotuitui, 1-16. https://doi.org/10.1080/117708 3X.2020.1767164

Kawharu, A. (2016). The Treaty of Waitangi exception in New Zealand's free trade agreements. Journal of International Law, 17(2), 286.

Kimel, M. (2015). What do the Toronto Pan Am Games 2015 have to do with social enterprise? Sojo. https://medium. com/sojo-stories/what-do-the-toronto-pan-am-games2015-have-to-do-with-social-enterprise-b41e60d7acc4

Kreshpaj, B., Orellana, C., Burström, B., Davis, L., Hemmingsson, T., Johansson, G., Kjellberg, K., Jonsson, J., Wegman, D. H., \& Bodin, T. (2020). What is precarious employment? A systematic review of definitions and operationalizations from quantitative and qualitative studies. Scandinavian Journal of Work, Environment and Health, 46(3), 235-247. https://doi.org/10.5271/sjweh.3875

Loosemore, M. (2016). Social procurement in UK construction projects. https://doi.org/10.1016/j. ijproman.2015.10.005

Lysons, K., \& Farrington, B. (2006). Purchasing and supply chain management (7th ed.). Pearson Education.

Ministry of Business, Innovation and Employment (MBIE). (n.d.-a). Government Procurement Charter. https://www.procurement.govt.nz/procurement/ principles-charter-and-rules/government-procurementcharter/

Ministry of Business, Innovation and Employment (MBIE). (n.d.-b). Removing barriers for New Zealand businesses. Retrieved from https://www.procurement.govt.nz/ broader-outcomes/increasing-access-for-new-zealandbusinesses/

Ministry of Business, Innovation and Employment (MBIE). (2017a). Briefing for the incoming minister. http://cera. govt.nz/sites/default/files/common/cera-briefing-for-theincoming-minister-december-2011-20120202.pdf

Ministry of Business, Innovation and Employment (MBIE). (2017b). Māori in the labour market. https://www.mbie. govt.nz/assets/c71b557b32/2017-monitoring-reportmaori-in-the-labour-market.pdf

Ministry of Business, Innovation and Employment (MBIE). (2019). Government procurement rules-Rules for sustainable and inclusive procurement (4th ed.). www.procurement.govt.nz

Ministry of Business, Innovation and Employment (MBIE). (2020a). Māori in the labour market - June 2020 quarter (unadjusted). (June), 14-16.

Ministry of Business, Innovation and Employment (MBIE). (2020b). Supplier diversity to increase through new procurement targets for Māori businesses. https://www.procurement.govt.nz/about-us/news/ supplier-diversity-to-increase-through-new-procurementtargets-for-maori-businesses/

Ministry of Business, Innovation and Employment (MBIE). (2021). Government procurement principles. https:// www. procurement.govt.nz/procurement/principlescharter-and-rules/government-procurement-principles/

Ministry of Foreign Affairs \& Trade. (n.d.). Government procurement. https://www.mfat.govt.nz/en/trade/freetrade-agreements/free-trade-agreements-in-force/ comprehensive-and-progressive-agreement-fortrans-pacific-partnership-cptpp/understanding-cptpp/ government-procurement/ 
Mccrudden, C. (2004). Using public procurement to achieve social outcomes. In Natural Resources Forum (Vol. 28). www.ams.mod.uk/ams/content/docs/toolkit/ams/policy/ $\mathrm{mcm} /$

McNeill, J. (2015). Insights into social procurement: From policy to practice. http://socialprocurementaustralasia. com/wp -content/uploads/2015/07/SPA-Insights-FromPolicy-to-Practice-2015FINAL.pdf.

Moewaka Barnes, H. M. (2009). The evaluation hikoi: A Māori overview of programme evaluation. Communities, (February), 1-39.

Mupanemunda, M. (2019). Social procurement through purchasing expenditure. Brotherhood of St Laurence 2017), 1-12. https://apo.org.au/node/261161

Nash, S., \& Jackson, W. (2020). Increase to supplier diversity through new procurement target for Māori Business. Beehive.govt.nz. https://www.beehive.govt.nz/release/ increase-supplier-diversity-through-new-procurementtarget-maori-business

Pool, I. (2015). Colonization and development in New Zealand between 1769 and 1900: The seeds of Rangiatea. Demographic transformation and socioeconomic development series (Vol. 3). Springer.

Short, S. (2021). Understanding a Tiriti-based approach to social procurement. University of Otago.

Simmons, L. (2017, March). Economic justice. In Encyclopedia of social work on-line (pp. 1-27) National Association of Social Workers Press and Oxford University Press. http://socialwork.oxfordre. com/view/10.1093/acrefore/9780199975839.001.0001/ acrefore9780199975839-e-1266?print=pdf

Simpson, P. M., Siguaw, J. A., \& White, S. C. (2002). Measuring the performance of suppliers: An analysis of evaluation processes. Journal of Supply Chain Management, 38(4), 29-41. https://doi.org/10.1111/ j.1745-493X.2002.tb00118.x

Statistics New Zealand. (2020). Child poverty statistics: Year ended June 2019. https://www.stats.govt.nz/informationreleases/child-poverty-statistics-year-ended-june-2019

Supply Nation. (2018). Supply Nation today launched a social return on investment (SROI) report. https://supplynation. org.au/wp-content/uploads/2018/05/Supply-Nationlaunches-a-Social-Return-on-Investment-Report.pdf

Tadelis, S. (2012). Public procurement design: Lessons from the private sector. International Journal of Industrial Organization, 30(3), 297-302. https://doi.org/10.1016/j. ijindorg.2012.02.002

Te Matarau A Māui. (n.d.). Iwi, Māori collectives and Māori business growth. http://www.tematarau.co.nz/strategy/ iwi-maori-collectives-and-maori-business-growth/

Toronto City Council. (2016). City of Toronto Social Procurement Program. http://www.toronto.ca/legdocs/ mmis/2016/ex/bgrd/backgroundfile-91818.pdf

Toronto2015. (2015). TO2015: Spend data since inception in January 01, 2010. http://images.toronto2015.org/system/ asset_pdfs/1414/original/to2015-procurement-spenddata.pdf

Te Puni Kōkiri (TPK). (2021). Suppliers (Māori businesses). https://www.tpk.govt.nz/en/a-matou-kaupapa/maorieconomic-resilience/progressive-procurement/suppliersmaori-businesses
Troje, D., \& Andersson, T. (2020). As above, not so below: Developing social procurement practices on strategic and operative levels. Equality, Diversity and Inclusion, (2013). https://doi.org/10.1108/EDI-03-2020-0054

Troje, D., \& Kadefors, A. (2018). Employment requirements in Swedish construction procurement-institutional perspectives. Journal of Facilities Management, 16(3), 284-298. https://doi.org/10.1108/JFM-09-2016-0038

Trust Tairāwhiti. (2020). Te Tairāwhiti region's economic recovery-How can we bounce back better? https://www.trusttairawhiti.nz/news/te-tairawhiti-regionseconomic-recovery-how-can-we-bounce-back-better/

Wisner, J., Tan, K., \& Leong, G. (2012). Principles of supply chain management: $A$ balanced approach (3rd ed.). Cengage Learning. 